\title{
Factors Influencing Consumers’ Online Repurchasing Behavior: A Review and Research Agenda
}

\author{
Huaiqin Li ${ }^{1}$, Jinhwan Hong ${ }^{2 *}$ \\ ${ }^{1}$ School of Business, Linyi University, Linyi, China; ${ }^{2}$ Department of Business Administration, The University of Suwon, Suwon, \\ South Korea.

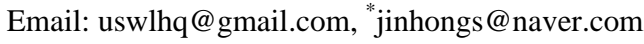

Received September $5^{\text {th }}, 2013$; revised October $4^{\text {th }}, 2013$; accepted November $1^{\text {st }}, 2013$

Copyright (C) 2013 Huaiqin Li, Jinhwan Hong. This is an open access article distributed under the Creative Commons Attribution License, which permits unrestricted use, distribution, and reproduction in any medium, provided the original work is properly cited.

\begin{abstract}
With the rapid development of E-commerce activities, it is of critical importance to identify the determinants of repurchase intention to both researchers and practitioners. This research attempts to explain the relationship between online shopping businesses and customers by testing the model incorporating the mechanisms of perceived value, satisfaction, and consumers' repurchase intention.
\end{abstract}

Keywords: Customer Perceived Value; Satisfaction; Switching Barriers; Repurchase Intention

\section{Introduction}

Web-based services have low entry barriers by its nature. If one service is created, a number of comparable alternative web-based services follow, resulting in a high switching rate between those services by users [1]. Thus, shopping sites' providers are very eager to identify the conditions that lead to long-running shopping sites. Accordingly, continuance intention has become an important subject of study in the consumer behavior research area in E-commerce.

The competitive advantage of E-commerce is obtained from customer loyalty and retention for repeat purchases $[2,3]$. Thus, the identification of determinants of repurchase intention is of critical importance to both researchers and practitioners. However, according to previous research of Hellier et al. [2] on consumer, repurchase intention has been largely fragmented, and few studies have tested a structural model based on a verified framework. Recently, researchers called for more efforts in order to better understand customer behavior for online shopping [4,5]. On the one hand, this research attempts to explain the relationship between Internet shopping businesses and customers by testing the model incorporating the mechanisms of perceived value, satisfaction, and behavior (repurchase intention). On the other hand, it takes cus-

\footnotetext{
"Corresponding author.
}

tomer repurchase intention as the final output variables.

\section{Literature Review}

\subsection{Customer Perceived Value}

The study of customer perceived value is becoming significantly more important, both in research and in practice. Scientists and practitioners have recognized the power of the customer perceived value concept in identifying value for customers and managing customer behavior [6,7]. The goal of customer perceived value research is to describe, analyze, and make empirically measurable the value that companies create for their customers and to link these insights to further marketing constructs.

Customer perceived value is defined as "the customers overall assessment of the utility of a product, based on perceptions of what is received and what is given” [8]. In the satisfaction literature, equity theory considers the ratio of the customer's perceived outcome/input to that of the service provider's outcome/input [9]. Perceived value is regarded as a better variable for prediction of repurchase intention than customer satisfaction [10], because the perception of value is the overall assessment of the benefit received from the product or service depend on gain-and-lost assessment and interpreted it as the perception of value [11].

The level of perceived value can be measured in two 
major approaches. The first one defines perceived value as a construct comprised of two parts, one is benefits received and the other is the sacrifices made [10,12]. The benefits component include the perceived quality of service and a series of psychological benefits [8], and sacrifices component includes monetary and non-monetary factors such as time, risk and convenience [12]. The second approach defines customer perceived value as a multidimensional construct by Woodruff; Sweeney \& Soutar; Roig et al. [13-15]. Sheth et al. [16] defined perceived value as a multidimensional construct composed of five core values which are social, emotional, functional, epistemic and conditional.

\subsection{Customer Satisfaction}

Customer satisfaction studies remain the single largest category of marketing research, demonstrating the practical importance of this construct. In marketing research, various models and theories have been developed in order to define and explain the cumulative satisfaction, measuring it as the general level of satisfaction based on all experiences with the firm. A satisfied customer is viewed as indispensable means of creating sustainable advantage in the current competitive environment [17].

Customer satisfaction is generally defined in the marketing literature as the discrepancy between a customer's expectations and perceptions $[18,19]$. In this viewpoint, customer satisfaction is delineated as the consumer's evaluation that products or services meet or fall to meet the customer's expectations [20,21]. Moreover, "satisfaction is a judgment that a product or service feature, or the product or service itself, provided (or is providing) a pleasurable level of consumption-related fulfillment, including levels of under or over-fulfillment" [19]. Choi [22] also mentioned that "one simple approach to the concept of customer satisfaction is to understand it as a perceived value".

In recent years, most researchers consider that satisfaction is a combination of cognitive and affective response to service encounters. The satisfaction literature is focused on the nature of the cognitive and affective processes that result in the consumer's state of mind referenced to as satisfaction [23]. The cognitive dimension is individuals' accumulate information from direct or indirect experience, while the affective dimension is his positive or negative evaluation [24]. According to this stream of satisfaction research, past literature has concentrated on describing satisfaction by the consumers' evaluation. Yi [21] categorized customer satisfaction definitions either as an evaluation process or as an outcome of evaluation process. Yi [21] and Fornell [25] describe satisfaction as an evaluation process where as Tse and Wilton [26] describes satisfaction as an outcome of evaluation process.

\subsection{Switching Barriers}

Jones et al. [27] considered that switching barriers are factors that make it difficult or costly for a customer to change service providers. These factors include three types of switching barriers: strong interpersonal relationships (the strength of the personal bonds that may develop between the employees of a supplier and the customer), high switching costs (the customers perception of the time, money and effort associated with changing supplier) and attractiveness of alternatives, which refers to whether viable alternatives exist in the market. Ping [28] also classified switching barriers into three factors: alternative attractiveness, switching cost, investment in a relationship.

Kuisma et al. described switching barriers include search costs, transaction costs, learning costs, loss of loyal customer discounts, loss of established habits and relationships, and risk of the unknown [29]. Switching costs are not only economic in nature [1], but also can be psychological and emotional [2]. Factors influencing switching costs vary in accordance with the type of products, businesses, and customers. Gruen et al. [30] used the term "continuance commitment" as a measure of the extent to which a buyer was psychologically bound to a seller. This constraint-based force binds the consumer to the e-retailer out of need [31]. Essentially, this type of determinant constitutes a form of dependence and reflects the consumer's awareness that changing to another online store would involve considerable switching costs. Burnham et al. [32] suggested that switching barriers prevented switching when there was a negative situation, such as a temporary decline in service quality. The barriers allow time for the provider to rebuild to higher satisfaction levels.

\subsection{Repurchase Intention}

In this study, we examined online repurchase intention instead of studying the online consumers' actual behavior because, based on the theory of reasoned action proposed by Ajzen and Fishbein [33]. Intention is considered the best immediate factor in the relationship between attitude and behavior, it is affected by attitude and subjective norms, and is appropriate to test consumers' behavior. This implies that behavior is decided by individual intention. Online customer retention is a hot issue in marketing areas. Researchers have studied online customer retention in different contexts, such as "online repurchase intention” Khalifa, M. [34], "Continue to shop online" [35] Mouakket, S., and so on.

Definition of repurchase intention, different scholars have different views. In this study, customer repurchase intention is defined as the individual's judgment about buying a service again, the decision to engage in future 
activity with a service provider and what form this activity will take $[2,36]$.

Scholars have focused on different aspects of repurchase intention. For example, regarding the underlying logic of the ECT model as described by Oliver [37] and Bhattacherjee [38,39], the model posits that confirmation and satisfaction are the primary determinants of the intention to repurchase. Jones [40] considered that switching barriers directly affect repurchase Intention. Customers' repurchase intention depends on the value obtained in their previous transactions [41] such as: appropriate performance criteria (benefits), competition, and cost considerations.

\section{Hypothesis and Research Model}

\subsection{Customer Perceived Value and Customer Satisfaction, Switching Barriers, Repurchase Intention}

Woodruff [13] argues that perceived value represents customer cognition of the nature of relational exchanges with their suppliers, and satisfaction reflects customers' overall feeling derived from the perceived value. On the basis of the behavioral model [33], affect is significantly influenced by cognition. And empirical evidences show that customer-perceived value has a positive effect on customer satisfaction with a supplier [42]. Thus, it is proposed that:

H1. Customer perceived value is positively associated with customer satisfaction.

The evaluation of value is subjective in nature [43]. Consumers judge stimuli against purchase expectations and desire to determine a net value outcome $[13,44]$. The customer value focuses on high quality and/or low price compared to alternatives. A price-quality comparison is often viewed as a critical determinant to purchase decisions and switching behavior [41], and consequently, can create strong exit barriers. In other words, as buyers perceive that they are getting a better deal (i.e. better economic value, or higher quality, or lower price compared to competitors), they will perceive the costs associated with switching from this supplier as being higher.

H2. Customer perceived value is positively associated with switching barriers.

Scholars and researchers have been continually interested in perceived value which brought about widely distribution of research and study literatures in various journals such as: Journal of Marketing Research [12], Journal of Retailing [10], Journal of Travel Research [45] and similar to many other scholars [46,47], in which explained that perception of value had positive influence on repurchase intention. According to Arch, Lise \& Robert [48], and Zeithaml [8], their studies also show that customer perceived value takes positive effect on customer satisfaction and customer repurchase intention.

H3. Customer perceived value is positively associated with repurchase intention.

\subsection{Customer Satisfaction and Repurchase Intention}

Future purchase intentions have a relationship with customer satisfaction [49,50]. Customer satisfaction is an antecedent of repurchases intention. Customers evaluate future purchase intentions based on the value obtained from previous experiences, with relationship benefits, as a proxy for expectations of future benefits.

In general, that number of previous researches can be found that there is a strong, positive relationship between satisfaction and repurchase intentions. (e.g. Anderson and Fornell [51], Rust and Zahorik [52]). It can be confirmed that satisfied consumers are more likely to buy again or to buy more in future transactions than dissatisfied customers (e.g. Reichheld [53], Michael [54], Nigel \& Jim [55] believe that the improvement of customer satisfaction will increase customer repurchase intention, and customer satisfaction is the antecedents of the customer repurchase intention and it can make a certain degree of interpretation of the customer repurchase intention).

H4. Customer satisfaction is positively associated with repurchase intention.

\subsection{Switching Barriers and Satisfaction, Repurchase Intention}

In recent years, numerous studies in the service sector have proposed and empirically validated the association with customer satisfaction and behavioral intentions such as customer revisit and switching intentions [10]. Cronin et al. [10] empirically tested the significant linkage between customer satisfaction and switching intention. The research of Lund [56] shows that barriers may enhance the probability of remaining in a social relationship. She found that the barrier variables were better predictors of whether a romantic relationship would continue than the positive pull variables. In addition, some scholars consider that, as a key moderating variable, switching costs can significantly influence customer loyalty through the determinants such as customer satisfaction [17,57,58], and perceived value [13]. Therefore, we proposed:

H5. Customer satisfaction is positively associated with switching barriers.

Several conceptual and empirical studies have posited switching barriers as a key determinant of repurchase intentions. Wathne et al. [41], drawing on economic sociology literature, suggested that switching providers would mean sacrificing the utility of an existing relationship. Therefore, switching barriers would be a psychological loss that customers do not want to incur. Fur- 


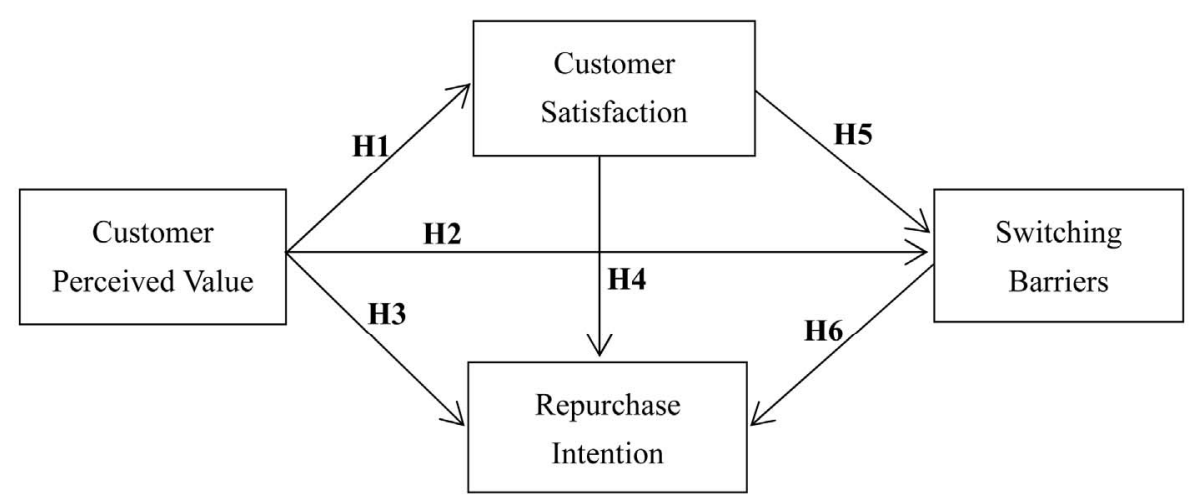

Figure 1. Research model.

thermore, a study of Jones et al. [40] provided empirical support for the view that consumers who felt "locked in" were more likely to remain with a provider. Therefore, we proposed:

H6. Switching barriers is positively associated with repurchase intentions.

The relationship of variables as hypothesized is depicted in the Figure 1.

\section{REFERENCES}

[1] B. Vatanasombut, M. Lgbaria, A. Stylianou and W. Rodgers, "Information System Continuance Intention of Web Based Applications Customers: The Case of Online Banking,” Information and Management, Vol. 45, No. 7, 2008, pp. 419-428. http://dx.doi.org/10.1016/j.im.2008.03.005

[2] P. K. Hellier, G. M. Geursen, R. A. Carr and J. A. Rickard, "Customer Repurchase Intention, a General Structural Equation Model,” European Journal of Marketing, Vol. 37, No. 11-12, 2003, pp. 1762-1800. http://dx.doi.org/10.1108/03090560310495456

[3] H. Tsai and H. Huang, "Determinants of E-Repurchase Intentions: An Integrative Model of Quadruple Retention Drivers," Information \& Management, Vol. 44, No. 3, 2007, pp. 231-239.

http://dx.doi.org/10.1016/j.im.2006.11.006

[4] Z. Yang, R. T. Peterson and S. Cai, "Service Quality Dimensions of Internet Purchasing: An Exploratory Analysis,” Journal of Services Marketing, Vol. 17, No. 7, 2003, pp. 685-700. http://dx.doi.org/10.1108/08876040310501241

[5] V. A. Zeithaml, A. Parasuraman and A. Malhotra, "Service Quality Delivery through Web Sites: A Critical Review of Extant Knowledge," Journal of the Academic of Marketing Science, Vol. 30, No. 4, 2002, pp. 362-375. http://dx.doi.org/10.1177/009207002236911

[6] M. D. Johnson, A. Herrmann and F. Huber, "The Evolution of Loyalty Intentions,” American Marketing Association, Vol. 70, 2006, pp. 122-132.

[7] D. Setijono and J. J. Dahlgard, "Customer Value as a Key Performance Indicator (KPI) and a Key Improvement Indicator (KII)," Measuring Business Excellence, Vol. 11, No. 2, 2007, pp. 44-61.

\section{http://dx.doi.org/10.1108/13683040710752733}

[8] V. A. Zeithaml, “Consumer Perceptions of Price, Quality, and Value: A Means-End Model and Synthesis of Evidence," Journal of Marketing, Vol. 52, No. 3, 1988, pp. 2-22. http://dx.doi.org/10.2307/1251446

[9] R. L. Oliver and W. S. DeSarbo, "Response Determinants in Satisfaction Judgments," Journal of Consumer Research, Vol. 14, No. 2, 1998, pp. 495-507.

[10] J. J. Cronin Jr., M. K. Brady and G. T. M. Hult, “Assessing the Effects of Quality, Value, and Customer Satisfaction on Consumer Behavioral Intentions in Service Environments," Journal of Retailing, Vol. 76, No. 2, 2000, pp. 193-218. http://dx.doi.org/10.1016/S0022-4359(00)00028-2

[11] V. A. Zeithaml, L. L. Berry and A. Parasuraman, "The Behavioral Consequences of Service Quality,” Journal of Marketing, Vol. 60, No. 2, 1996, pp. 31-46. http://dx.doi.org/10.2307/1251929

[12] W. B. Dodds, K. B. Monroe and D. Grewal, "Effects of Price, Brand, and Store Information on Buyers' Product Evaluations,” Journal of Marketing Research, Vol. 23, No. 3, 1991, pp. 307-319. http://dx.doi.org/10.2307/3172866

[13] R. Woodruff, "Customer Value: The Next Source for Competitive Advantage," Journal of the Academy of Marketing Science, Vol. 25, No. 2, 1997, pp. 139-153. http://dx.doi.org/10.1007/BF02894350

[14] J. C. Sweeney, G. N. Soutar and L. W. Johnson, "The Role of Perceived Risk in the Quality-Value Relationship: A Study in a Retail Environment,” Journal of Retailing, Vol. 75, No. 1, 1999, pp. 77-105. http://dx.doi.org/10.1016/S0022-4359(99)80005-0

[15] J. C. F. Roig, J. S. Garcia, M. A. M. Tena and J. L. Monzonis, "Customer Perceived Value in Banking Services," International Journal of Bank Marketing, Vol. 24, No. 5, 2006, pp. 266-283. http://dx.doi.org/10.1108/02652320610681729

[16] J. N. Sheth, B. I. Newman and B. L. Gross, "Why We Buy What We Buy: A Theory of Consumption Values," Journal of Business Research, Vol. 22, 1991, pp. 159-170. http://dx.doi.org/10.1016/0148-2963(91)90050-8

[17] R. L. Oliver, "Whence Consumer Loyalty?” Journal of Marketing, Vol. 63, No. 4, 1999, pp. 33-44. 
http://dx.doi.org/10.2307/1252099

[18] D. Moshavi, "He Said, She Said: Gender Bias and Customer Satisfaction with Phone-Based Service Encounters,” Journal of Applied Social Psychology, Vol. 34, No. 1, 2004, pp. 162-176. http://dx.doi.org/10.1111/j.1559-1816.2004.tb02542.x

[19] R. L. Oliver, "Satisfaction: A Behavioral Perspective on the Consumer,” McGraw Hill, New York, 1997.

[20] R. L. Oliver and J. E. Swan, "Consumer Perceptions of Interpersonal Equity and Satisfaction in Transactions: A Field Survey Approach,” Journal of Marketing, Vol. 53, No. 2, 1989, pp. 21-35. http://dx.doi.org/10.2307/1251411

[21] Y. Yi, “A Critical Review of Consumer Satisfaction," Review of Marketing, No. 4, 1990, pp. 68-123.

[22] T. Y. Choi and R. Chu, "Determinants of Hotel Guests' Satisfaction and Repeat Patronage in the Hong Kong Hotel Industry," International Journal of Hospitality Management, Vol. 20, No. 3, 2001, pp. 277-297. http://dx.doi.org/10.1016/S0278-4319(01)00006-8

[23] W. Jaronski, "Customer Satisfaction and Loyalty Research: A Bayesian Network Approach,” Ph.D. Thesis, Limburgs University, 2004,

[24] D. Florence, S. Llosa and C. Orshinger, "Words, Words, Mere Words? An Analysis of Services Customers' Perception of Evaluative Concepts," Quality Management Journal, Vol. 13, No. 2, 2006, pp. 46-53.

[25] C. Fornell, “A National Customer Satisfaction Barometer: The Swedish Experience,” Journal of Marketing, Vol. 56, No. 1, 1992, pp. 6-21. http://dx.doi.org/10.2307/1252129

[26] D. K. Tse and P. C. Wilton, "Models of Consumer Satisfaction Formation: An Extension,” Journal of Marketing Research, Vol. 25, No. 2, 1988, pp. 204-212. http://dx.doi.org/10.2307/3172652

[27] M. A. Jones, D. L. Mothersbaugh and S. E. Beatty, "Switching Barriers and Repurchase Intentions in Services,” Journal of Retailing, Vol. 76, No. 2, 2000, pp. 259-274. http://dx.doi.org/10.1016/S0022-4359(00)00024-5

[28] R. A. Ping Jr., "The Effects of Satisfaction and Structural Constraints on Retailer Exiting, Voice, Loyalty, Opportunism, and Neglect,” Journal of Retailing, Vol. 69, No. 3, 1993, pp. 320-352.

http://dx.doi.org/10.1016/0022-4359(93)90010-G

[29] T. Kuisma, T. Laukkanen and M. Hiltunen, "Mapping the Reasons for Resistance to Internet Banking: A MeansEnd Approach," International Journal of Information Management, Vol. 27, No. 2, 2007, pp. 75-85. http://dx.doi.org/10.1016/j.ijinfomgt.2006.08.006

[30] T. W. Gruen, J. O. Summers and F. Acito, "Relationship Marketing Activities, Commitment, and Membership Behaviors in Professional Associations," Journal of Marketing, Vol. 64, No. 3, 2000, pp. 34-49. http://dx.doi.org/10.1509/jmkg.64.3.34.18030

[31] H. S. Bansal, G. H. G. McDougall, S. S. Dikolli and K. L. Sedatole, "Relating E-Satisfaction to Behavioral Outcomes: An Empirical Study,” Journal of Services Mar- keting, Vol. 18, No. 4, 2004, pp. 290-302. http://dx.doi.org/10.1108/08876040410542281

[32] T. A. Burnham, J. K. Frels and V. Mahajan, "Consumer Switching Costs: A Typology, Antecedents, and Consequences," Journal of the Academy of Marketing Science, Vol. 31, No. 2, 2003, pp. 109-126. http://dx.doi.org/10.1177/0092070302250897

[33] M. A. Fishbein and I. Ajzen, "Belief, Attitude, Intention and Behavior: An Introduction to Theory and Research," Addison-Wesley, Reading, 1975.

[34] M. Khalifa and V. Liu, "Online Consumer Retention: Contingent Effects of Online Shopping Habit and Online Shopping Experience,” European Journal of Information Systems, Vol. 16, No. 6, 2007, pp. 780-792. http://dx.doi.org/10.1057/palgrave.ejis.3000711

[35] S. Mouakket, "The Effect of Exogenous Factors on the Technology Acceptance Model for Online Shopping in the UAE,” International Journal Electronic Business, Vol. 7, No. 5, 2009, pp. 491-511. http://dx.doi.org/10.1504/IJEB.2009.028153

[36] V. A. Zeithaml, L. L. Berry and A. Parasuraman, "The Behavioural Consequences of Service Quality,” Journal of Marketing, Vol. 60, No. 2, 1996, pp. 31-46. http://dx.doi.org/10.2307/1251929

[37] R. L. Oliver, "A Cognitive Model of the Antecedents and Consequences of Satisfaction Decisions," Journal of Marketing Research, Vol. 17, No. 4, 1980, pp. 460-469. http://dx.doi.org/10.2307/3150499

[38] A. Bhattacherjee, "Understanding Information Systems Continuance: An Expectation-Confirmation Model,” MIS Quarterly, Vol. 25, No. 3, 2001, pp. 351-370. http://dx.doi.org/10.2307/3250921

[39] A. Bhattacherjee, "An Empirical Analysis of the Antecedents of Electronic Commerce Service Continuance," Decision Support Systems, Vol. 32, No. 2, 2001, pp. 201-214. http://dx.doi.org/10.1016/S0167-9236(01)00111-7

[40] M. A. Jones, "Satisfaction and Repurchase Intentions in the Service Industry: The Moderating Influence of Switching Barriers,” Ph.D. Thesis, The University of Alabama, Alabama, 1998.

[41] K. H. Wathne, H. Biong and J. B. Heide, "Choice of Supplier in Embedded Markets: Relationship and Marketing Program Effects,” Journal of Marketing, Vol. 65, No. 2, 2001, pp. 54-66. http://dx.doi.org/10.1509/jmkg.65.2.54.18254

[42] W. A. Eugene and F. Claes, "Foundation of the American Customer Satisfaction Index,” Total Quality Management, Vol. 11, No. 7, 2000, pp. 869-882. http://dx.doi.org/10.1080/09544120050135425

[43] S. Parry, J. Rowley, R. Jones and B. Kupiec-Teahan, "Customer-Perceived Value in Business-to-Business Relationships: A Study of Software Customers,” Journal of Marketing Management, Vol. 28, No. 7-8, 2012, pp. 887911. http://dx.doi.org/10.1080/0267257X.2012.698637

[44] P. E. Boksberger and L. Melsen, "Perceived Value: A Critical Examination of Definitions, Concepts and Measures for the Service Industry," Journal of Services Marketing, Vol. 25, No. 3, 2011, pp. 229-240. 
http://dx.doi.org/10.1108/08876041111129209

[45] J. F. Petrick and S. J. Beckman, “An Examination of the Construct of Perceived Value for the Prediction of Golf Travelers' Intentions to Revisit," Journal of Travel Research, Vol. 41, No. 4, 2002, pp. 38-45.

[46] J. L. M. Tam, “The Effects of Service Quality, Perceived Value and Customer Satisfaction on Behavioral Intentions,” Journal of Hospitality and Leisure Marketing, Vol. 6, No. 4, 2000, pp. 31-43.

[47] M. Pura, "Linking Perceived Value and Loyalty in Location-Based Mobile Services," Journal of Marketing Research, Vol. 28, No. 3, 1991, pp. 307-319.

[48] G. W. Arch, F. Lise and T. D. Robert, "Linking Service Quality, Customer Satisfaction and Behavior Intention,” Journal of Healthcare Marketing, Vol. 11, No. 4, 1989, pp. 5-17.

[49] P. G. Patterson, L. W. Johnson and R. A. Spreng, "Modeling the Determinants of Customer Satisfaction for Business to Business Professional Services," Journal of the Academy of Marketing Science, Vol. 25, No. 1, 1997, pp. 4-17. http://dx.doi.org/10.1007/BF02894505

[50] S. Durvasula, S. Lysonski, S. C. Mehta and B. P. Tang, "Forging Relationships with Services: The Antecedents that have an Impact on Behavioural Outcomes in the Life Insurance Industry," Journal of Financial Services Marketing, Vol. 8, No. 4, 2004, pp. 314-326. http://dx.doi.org/10.1057/palgrave.fsm.4770129

[51] E. W. Anderson and C. Fornell, "A Customer Satisfaction Research Prospectus,” In: R. T. Rust and R. Oliver, Eds., Service Quality: New Directions in Theory and Practice,
Sage Publications, Thousand Oaks, 1994, pp. 241-268. http://dx.doi.org/10.4135/9781452229102.n11

[52] R. T. Rust and A. J. Zahorik, "Customer Satisfaction, Customer Retention, and Market Share,” Journal of Retailing, Vol. 69, No. 2, 1993, pp. 193-215. http://dx.doi.org/10.1016/0022-4359(93)90003-2

[53] F. Reichheld, “The Loyalty Effect," Harvard Business School Press, Boston, 1996.

[54] M. D. Johnson, A. Gustafaaon, T. W. Andreassen, L. Lervik and J. Cha, "The Evolution and Future of National Customer Satisfaction Index Models," Journal of Economic Psychology, Vol. 22, No. 2, 2001, pp. 217-245. http://dx.doi.org/10.1016/S0167-4870(01)00030-7

[55] H. Nigel and A. Jim, "Handbook of Customer Satisfaction and Loyalty Measurment," 3rd Edition, Gower Publishing Co, Bodmin, 2002, pp. 22-23.

[56] M. Lund, "The Development of Investment and Commitment Scales for Predicting Continuity of Personal Relationships,” Journal of Social and Personal Relationships, Vol. 2, No. 1, 1985, pp. 3-23. http://dx.doi.org/10.1177/0265407585021001

[57] C. Fornell, “A National Customer Satisfaction Barometer: The Swedish Experience,” Journal of Marketing, Vol. 56, No. 1, 1992, pp. 6-21. http://dx.doi.org/10.2307/1252129

[58] G. Balabanis, N. Reynolds and A. Simintiras, "Bases of E-Store Loyalty: Perceived Switching Barriers and Satisfaction,” Journal of Business Research, Vol. 59, No. 2, 2006, pp. 214-224. http://dx.doi.org/10.1016/j.jbusres.2005.06.001 